\title{
Downregulation of both gene expression and activity of Hsp27 improved maturation of mouse oocyte in vitro
}

\author{
Jin-Juan Liư1,2, Xiang Mał2, Ling-Bo Cai², Yu-Gui Cui2 and Jia-Yin Liu*1,2
}

\begin{abstract}
Background: Heat shock protein 27 (Hsp27), a member of the small heat shock protein family, is an apoptosis regulator. Our previous proteomic study showed that Hsp27 mainly expressed in human oocyte, and that Hsp27 expression was downregulated in the ovaries derived from women with the polycystic ovary syndrome (PCOS), a well known endocrinal disorder with abnormal apoptotic activity and folliculogenesis. However, the exact effects of Hsp27 downregulation on oocyte development have not yet been clarified.

Methods: The expression of Hsp27 gene was downregulated in the mouse oocytes cultured in vitro using siRNA adenovirus infection, while the activity of $\mathrm{Hsp} 27$ was decreased by microinjection of polyclonal Hsp27 antibody into the cytoplasm of germinal vesicle (GV) oocytes. Oocyte maturation rate was evaluated by morphological observation. Early stage of apoptosis was determined using Annexin-V staining analysis and some critical apoptotic factors and cytokines were also monitored at both mRNA level by real time RT-PCR and protein expression level by immunofluorescence and western blot.

Results: Hsp27 expressed at high level in maturing oocytes. Infection with AdshHsp27, and microinjection of Hsp27 antibody into GV oocytes, resulted in the improved oocyte development and maturation. Germinal vesicle breakdown (GVBD) rates were significantly increased in two AdshHsp27-treated groups (88.7\%, 86.0\%) and Hsp27 antibodyinjected group (77.0\%) when compared with control (76.2\% in AdGFP, 64.4\% in IgG-injected), respectively. In addition, the rates of metaphase II (MII) development in two AdshHsp27-treated groups (73.8\%, 76.4\%) and Hsp27 antibodyinjected group (67.3\%) were higher than that in the controls (59.6\% in AdGFP, 55.1\% in lgG-injected). We also found that the rates of early stage of apoptosis in Hsp27 downregulated groups (46.5\% and 45.6\%) were higher than that in control group (34.1\%) after $8 \mathrm{~h}$ of IVM. Similarly, downregulation of Hsp27 caused a significantly enhanced the expression of apoptotic factors (caspase 8, caspase 3) and cytokines (bmp 15 and gdf 9).
\end{abstract}

Conclusions: Downregulation of Hsp27 improved the maturation of mouse oocytes, while increased early stage of apoptosis in oocytes by inducing the activation of extrinsic, caspase 8-mediated pathway.

\section{Background}

Polycystic ovarian syndrome (PCOS) is known as one of the most common endocrine disorders affecting approximately $5 \%-10 \%$ of women of reproductive age, and is characterized by chronic anovulation, hyperandrogenism and polycystic change in ovaries [1-4]. Accumulation of small antral follicles arrested in their development, with

\footnotetext{
* Correspondence: jyliu@njmu.edu.cn

1 Department of life science and technology, China Pharmaceutical University, Nanjing 210038, China

+ Contributed equally

Full list of author information is available at the end of the article
}

some atretic features, has been shown in ovaries subjected to PCOS [5-9]. Those atretic follicles were closely related to inside oocyte competence [10-12]. In addition, oocyte developmental competence was susceptible to derangement in PCOS, indicating that abnormal oocyte competence in PCOS was inextricably linked to abnormal follicular development [13-17].

In the ovary, apoptosis has been implicated in the granulose cells of atretic antral follicles and in regressing corpora lutea [18-22]. Derangement of apoptotic activity was observed in PCOS ovary tissue with the altered expres- 
sion of apoptotic-related regulators, including heat shock proteins (Hsp 90, Hsp 10), nuclear receptor subfamily, dickkopf homologue 3, and so on [23-26]. Hsp27, belonging to the small heat shock protein family, is a molecular chaperone protein involved in cellular protection in response to a variety of stresses such as heat shock, toxicants, injury, and oxidative stress [27-30]. Emerging evidences show that Hsp27 has strong anti-apoptotic properties by interacting directly with the caspase activation components in apoptotic pathways, consequently exerting protective effects in apoptosis-related injuries [31-34]. Interestingly, our previous proteomic study showed that Hsp27, a strong anti-apoptotic regulator, mainly localized in human oocyte, and was downregulated in the ovaries derived from women with PCOS [35]. However, the alteration of apoptotic activity, as well as effect of Hsp27, in PCOS ovaries needs to be further clarified.

Our hypothesis was that Hsp27 and its related pathways could have some effects on oocyte development, maturation, apoptosis and cell cycle in vivo and in vitro, and even participate in the follicle development and PCOS pathophysiology. In this pilot study, we firstly investigated the effect of Hsp27 downregulation on the meiotic progression and apoptosis in mouse oocyte model cultured in vitro.

\section{Methods}

Animals

The ICR mice were fed ad libitum with a standard diet and maintained in a temperature and light-controlled room $\left(20-22^{\circ} \mathrm{C}, 12 / 12 \mathrm{~h}\right.$ light/dark), in accordance with the Animal Research Committee Guidelines of Nanjing Medical University.

\section{Collection and culture of mouse oocytes}

Germinal vesicle (GV) oocytes were collected from 6week-old female ICR mice. 46-48 h previously, mice were received an intraperitoneal injection of $10 \mathrm{IU}$ of pregnant mare serum gonadotropin (PMSG, Folligon, Intervet, Castle Hill, Australia). Mice were sacrificed, and ovaries were placed in M2 medium (Sigma, St. Louis, MO). Cumulus oocyte complexes were recovered from ovaries by repeatedly puncturing the surface with fine steel needles, and cumulus cells were removed by hyaluronidase treatment (Sigma, $300 \mathrm{U} / \mathrm{ml}$ in PBS) under a dissecting microscope [36]. For preparation of zona pellucida-free oocytes, the oocytes were then exposed to acidic Tyrode's solution ( $\mathrm{pH}$ 2.5-3.0) with aspiration of the oocyte in and out of a glass micropipette to remove the zona pellucida [37]. Usually the zona pellucida was only partially dissolved and it could be removed by the pipette within 30s. Ding et al reported that zona-free oocytes didn't affect normal fertilization and blastocyst development [38].
After being immediately transferred to M2 and washed three times, 20-25 zona-free oocytes per group were put into $32 \mu$ droplets of maturation medium of M16 (Sigma) containing $10 \%$ fetal bovine serum (FBS; Invitrogen, Grand island, NY) in a $5 \%$ humidified atmosphere at $37^{\circ} \mathrm{C}$ under a layer of mineral oil. These prepared zona-free oocytes were then used in either control or treatment groups for further investigation.

\section{Recombinant adenovirus generation and infection}

The complementary DNA sequence of Hsp27 was obtained from GenBank (accession no. NM 013560). The potential target sequences for RNA interference (RNAi) were scanned with the siRNA Target Finder and Design Tool available from the Ambion Website [39]. The selected target sequences (shHsp27(1) and shHsp27(2)), 5'-GATCCCCGCTGGGAAGTCTGAACAGTTTCAAG AGAACTGTTCAGACTTCCCAGCTTTTTGGAAA-3' (sense) and 5'-GATCCCCCATGGCTACATCTCTCGGT TTCAAGAGAACCGAGAGATGTAGCCATGTTTTTGGAAA-3'(sense), corresponded to region 541-559 bp and 736-754 bp after the Hsp27 start codon, respectively. The negative control (randomized sequence) was: 5'GATCCCCCATGG CTAATCCGTTCTGCTTCAAGAGAGCAGAACGGATTAGCCATGTTTTTGGAAA-3'

$[40,41]$. These sequences were subcloned into pShuttle$\mathrm{H} 1$ according to the method used by Shen et al [42]. The pShuttle-H1-siRNA/Hsp27 was then recombined with backbone pAdEasy-1 in BJ5183 bacteria. Adenovirus generation, amplification and titer examinations were performed according to the simplified system described by $\mathrm{He}$ et al. [43]. Viral titer was determined by plaque assay in 293 cells.

Zona-free oocytes were incubated with adenovirus at the same multiplicity of infection (MOI) in medium at $37^{\circ} \mathrm{C}$ for specific durations as indicated in the following experiments.

\section{Microinjection of Hsp27 antibody into GV oocytes}

Hsp27 antibody (stock solution, $200 \mathrm{ug} / \mathrm{ml}$, goat polyclonal, Santa Cruz Biotechnology, Santa Cruz, CA) was microinjected into the cytoplasm of GV zona-intact denuded oocytes as described by Dai et al [44]. Goat normal IgG-injected (Santa Cruz, CA) oocyte and untreated oocytes were used as controls to assess injection itself damage. To determine maturation rate in vitro, the microinjected GV oocytes were cultured in M16 medium (Sigma) in a $5 \% \mathrm{CO}_{2}$ incubator at $37^{\circ} \mathrm{C}$ for $14 \mathrm{~h}$. Oocytes without GVs were scored as germinal vesicle breakdown (GVBD) stage, while those with a polar body scored as metaphase II (MII). The microinjection experiments were done 10-12 replicates, using a total of $>300$ oocytes. A Nikon Diaphot ECLIPSE TE 300 inverting microscope (Nikon UK Ltd, Kingston upon Thames, Surrey, UK) 
equipped with Narishige MM0-202N hydraulic threedimensional micromanipulators (Narishige Inc., Sea Cliff, NY) was used. Microinjection was completed in $40 \mathrm{~min}$, with volume of about 5-7 pl per oocyte.

\section{Annexin-V staining in oocytes}

Staining was performed with an Annexin-V kit according to the manufacturer's instructions (KenGentec, Nanjing, China). Annexin-V, a phospholipid-binding protein, detects the translocation of phospholipid phosphatidylserine (PS) from the inner to the outer cytoplasmic membrane, which is known to occur during the early stages of apoptosis. At the same time, samples were also stained with propidium iodide (PI) to distinguish live cells from dead cells. Briefly, zona pellucida-free oocytes infected with siRNA adenovirus via co-culturing for $1.5 \mathrm{~h}$ and $8 \mathrm{~h}$ were washed twice in PBS and stained with $500 \mu \mathrm{l}$ of binding buffer, which contained $5 \mu \mathrm{l}$ Annexin-V-fluorescein isothiocyanate (FITC) and $5 \mu \mathrm{l} \mathrm{PI} \mathrm{for} \mathrm{5-15} \mathrm{min} \mathrm{in} \mathrm{the}$ dark. Following this, samples were mounted on siliconized slides and observed under a laser confocal scanning microscope (ZEISS Fluorescent Microsystems, Göttingen, Germany).

\section{Real time RT-PCR analysis}

To determine mRNA abundance, real-time RT-PCR analysis was performed using ABI 7300 (Applied Biosystems,
Foster City, CA). RNA isolation was accomplished using the RNeasy Micro Kit (Qiagen, Valencia, CA) from the pooled oocytes (20-25 oocytes/tube). In vitro reverse transcription was carried out using Sensiscript Reverse Transcription Kit (Qiagen) with oligo-dT primer at $37^{\circ} \mathrm{C}$ for 60 minutes. For the real time RT-PCR reaction, cDNAs were used as templates for amplification to quantify the steady-state mRNA levels of the tested genes using Quanti Tect SYBR Green PCR Kits (Takara Shuzo Co Ltd, Kyoto, Japan). Relative quantitation of target gene expression was evaluated by the 2(-Delta Delta Ct) method [45], and the experiment was repeated at least three times using different sets of oocytes. In our study, beta-actin and GAPDH gene were used as the internal standards referred to similar papers $[46,47]$. To ensure only target gene sequence-specific, non-genomic products were amplified by real-time RT-PCR, careful design and validation of each primer pair. Primers used for real time RT-PCR are shown in Table 1.

\section{Immunofluorescence}

Oocytes of different treatment groups were fixed in $4 \%$ paraformaldehyde in PBS (pH7.4) for at least $30 \mathrm{~min}$ at room temperature and then incubated in permeabilization buffer $(0.5 \%$ Triton X-100 in $20 \mathrm{mM}$ Hepes $3 \mathrm{mM}$ $\mathrm{MgCl}_{2}, 50 \mathrm{mM} \mathrm{NaCl}, 300 \mathrm{mM}$ sucrose, and $0.02 \% \mathrm{NaN}_{3}$ )

Table 1: Primer sequences used for quantitative real-time PCR reactions.

\begin{tabular}{|c|c|c|c|c|}
\hline Primer name & Genbank accession number & Primer sequence & Location & Product size (bp) \\
\hline \multirow[t]{2}{*}{ Hsp27 } & NM 013560 & F: 5'-GCCGCACCAGCCTTCAGC-3' & $357-374$ & 147 \\
\hline & & R: 5'-CACGCCTTCCTTGGTCTTCACT-3' & $482-503$ & \\
\hline \multirow[t]{2}{*}{ Caspase 3} & NM 009810 & F: 5'-ATGGGAGCAAGTCAGTGGAC-3' & $128-147$ & 137 \\
\hline & & R: 5'-CGTACCAGAGCGAGATGACA-3' & $245-264$ & \\
\hline \multirow[t]{2}{*}{ Caspase 8} & NM 001080126 & F: 5'-TGAAGGACAGAAAAGGAACAGA-3' & $996-1017$ & 191 \\
\hline & & R: 5'-CTTGTCACCGTGGGATAGGATA-3' & $1165-1186$ & \\
\hline \multirow[t]{2}{*}{ Caspase 9} & NM 015733 & F: 5'-GGCGGAGCTCATGATGTCTGTG-3' & $757-778$ & 269 \\
\hline & & R: 5'-TTCCGGTGTGCCATCTCCATCA-3' & $1004-1025$ & \\
\hline \multirow[t]{2}{*}{ Cytochrome $c$} & $\underline{X R \quad 034017}$ & F: 5'-GGAGGCAAGCATAAGACTGG-3' & $219-239$ & 214 \\
\hline & & R: 5'-GTCTGCCCTITCTCCCTTCT-3' & $413-432$ & \\
\hline \multirow[t]{2}{*}{ Bmp15 } & NM 009757 & F: 5'-CTGACGACCCTACATTGCCCT-3' & $467-487$ & 232 \\
\hline & & R: 5'-TGTACATGCCAGGAACCTCTGG-3' & $677-698$ & \\
\hline \multirow[t]{2}{*}{ Gdf9 } & NM 008110 & F: 5'-TCCCAAACCCAGCAGAAGTC-3' & $426-445$ & 195 \\
\hline & & R:5'-GGAGGAGGAAGAGGCAGAGTTG-3' & $609-620$ & \\
\hline \multirow[t]{2}{*}{ GAPDH } & NM 008084 & F: 5'-AGGTTGTCTCCTGCGACTTCA-3' & $843-903$ & 216 \\
\hline & & R: 5'-GGGTGGTCCAGGGTTTCTTACT-3' & 1048-1068 & \\
\hline \multirow[t]{2}{*}{ beta-actin } & NM 007393 & F:5'-GAGACCTTCAACACCCCAGC-3' & $452-471$ & 263 \\
\hline & & R:5'-ATGTCACGCACGATTTCCC-3' & $696-714$ & \\
\hline
\end{tabular}




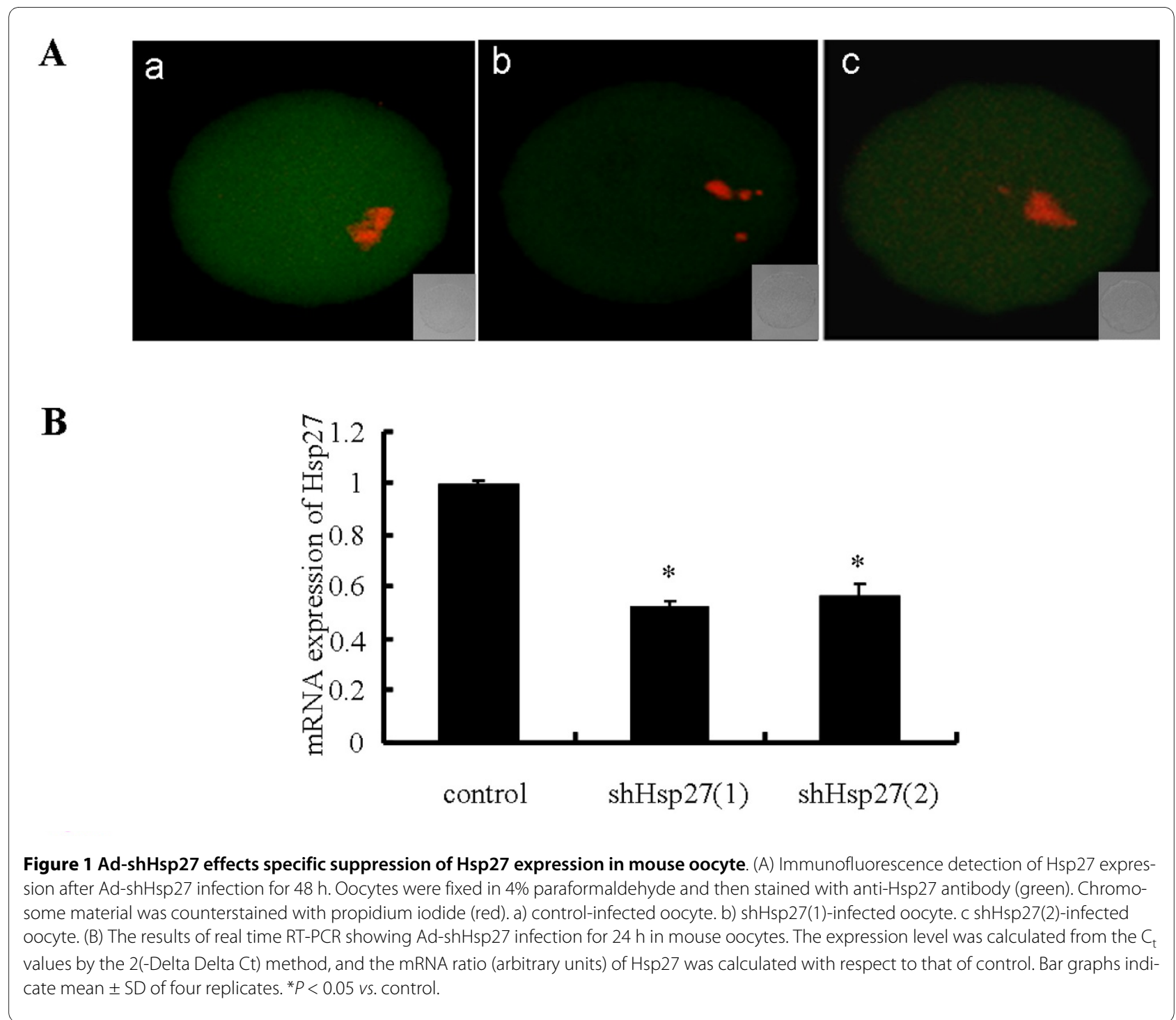

for $30 \mathrm{~min}$ at $37^{\circ} \mathrm{C}$, followed by blocking in $1 \%$ BSA for 1 $\mathrm{h}$ at room temperature. They were then incubated with Hsp27 antibody (1:100, Santa Cruz, CA), goat polyclonal anti-gdf 9 antibody (1:100, Santa Cruz, CA), rabbit polyclonal anti-cleaved-caspase 3 antibody (1:300; Cell Signaling, Danvers, MA), rabbit polyclonal anti-cleavedcaspase 8 antibody (1:200; Abcam, Cambridge, MA), rabbit monoclonal anti-caspase 9 antibody (1:200; Abcam) and mouse monoclonal cyctochrome $c$ antibody (1:100, Santa Cruz) at $4^{\circ} \mathrm{C}$ overnight. After washing, oocytes were incubated with a fluorescein isothiocyanate (FITC)conjugated secondary antibody (1:100; Beijing ZhongShan Biotechnology Co., Beijing, China) for $1 \mathrm{~h}$ at $37^{\circ} \mathrm{C}$, and DNA was counterstained with PI (Sigma). Finally, oocytes were mounted on glass slides with DABCO and examined using ZEISS 510 laser confocal microscopy (ZEISS Fluorescent Microsystems, Göttingen, Germany).

\section{Western blot analysis}

Oocytes of different treatment groups (1000 oocytes/ sample) were collected and added immediately into the cell lysis composed of $7 \mathrm{M}$ urea, $2 \mathrm{M}$ thiourea, and $4 \%$ CHAPS (W/V) and 1\% DTT (W/V), 1\% Cocktail (V/V). Proteins were extracted and separated by SDS-PAGE, and transferred onto a polyvinylidene difluoride (PVDF) membrane (GE Healthcare, San Francisco, CA). Following transfer, the membranes were blocked in Tris-buffered saline (TBS) containing 5\% skim milk for $1 \mathrm{~h}$ at room temperature and then incubated overnight with primary antibodies for cleaved-caspase 3 (1;500; Cell Signalling), cleaved-caspase 8 (1:1000; Abcam), caspase 9 (1:1000, Abcam), Hsp27(1:200; Santa Cruz), and $\beta$-tubulin (1:1000; Abcam) at $4^{\circ} \mathrm{C}$. After washing 3 times in TBST for $10 \mathrm{~min}$ each time, the membrane was incubated for 1 $\mathrm{h}$ at $37^{\circ} \mathrm{C}$ with horseradish peroxidase (HRP)-conjugated secondary antibody (Beijing ZhongShan, Beijing, China). 


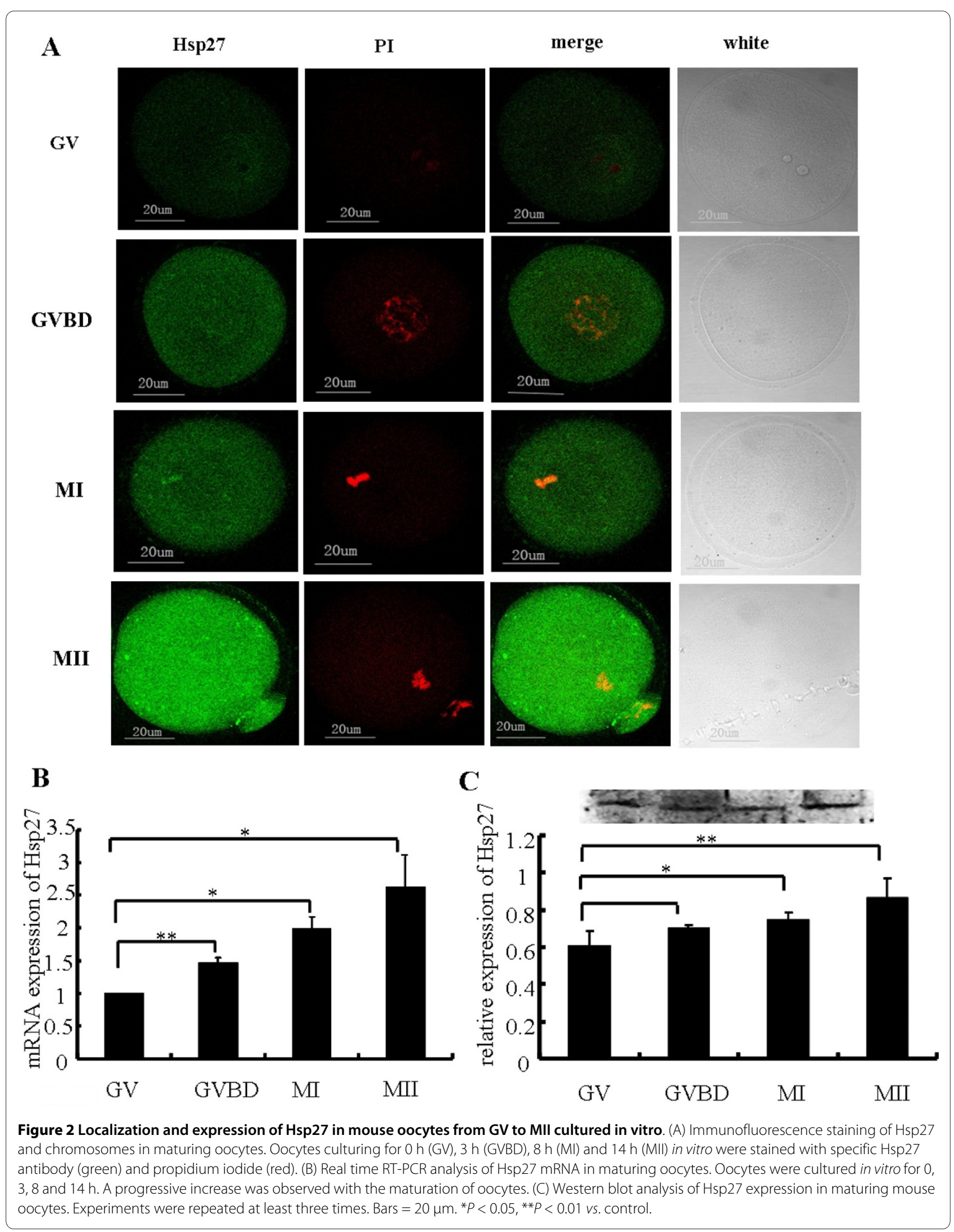


Table 2: Maturation of mouse oocytes after microinjecting of Hsp27 antibody at $3 \mathrm{~h}$ and $14 \mathrm{~h}$ of in vitro culture.

\begin{tabular}{lccc}
\hline Treatment & Total & $\begin{array}{c}\text { No. of oocytes (\%) } \\
\text { Germinal vesicle breakdown }\end{array}$ & Metaphase II \\
\hline Control & 312 & $210(67.3)$ & $186(59.6)$ \\
lgG & 323 & $208(64.4)$ & $178(55.1)$ \\
Antibody & 365 & $281(77.0)^{* *}$ & $246(67.3)^{* *}$ \\
\hline
\end{tabular}

** Values are statistical significance at $P<0.01$ (vs. $\lg \mathrm{G})$.

The membrane was then washed 3 times in TBS-Tween (TBST) for $10 \mathrm{~min}$ each, and processed using an enhanced chemiluminescence detection system (Alpha Innotech, San Leandro, CA). The molecular weights of the detected proteins were deduced by comparison with recombinant molecular weight standards (New England BioLabs, Ipswich, MA).

\section{Statistical analysis}

Each experiment was repeated at least three times. All data are presented as the mean \pm SD, and one-way analysis of variance and a log linear model were used to compare the mRNA and protein levels. Chi-square analysis was used to compare the rates of oocyte maturation and early stage of apoptosis. A value of $P<0.05$ was considered statistically significant, and if $\mathrm{P}<0.01$, it was noted.

\section{Results}

Construction of recombinant adenovirus Ad-shHsp27 and its expression

AD-293 cells were infected by the adenoviruses packaged with hairpin siRNA targeted against Hsp27/control. The results showed that the suppression rate of $\mathrm{Hsp} 27$ expression was as high as $75 \%$ vs. control (Data not shown, $P<$ 0.05 ) after infecting with Ad-shHsp27 and control for 48 h.

To examine the reduction degree of Hsp27 mRNA in mouse oocytes after infected with Ad-shHsp27 adenovirus, real time RT-PCR was performed. As Figure 1B displayed, Ad-shHsp27 significantly reduced endogenous Hsp27 mRNA abundance in mouse oocytes (50\%). The suppression degree of $\mathrm{Hsp} 27$ at protein level was detected by immunofluorescence (Figure 1A), which was in accor- dance with the real time PCR. These results suggested that the knockdown of Hsp27 expression by Ad-shHsp27 infecting was effective. Therefore, these two siRNA were chosen for the subsequent experiments.

\section{Localization and expression of Hsp27 in the maturing oocytes}

The localization of Hsp27 protein in maturing mouse oocytes was showed in Figure 2A. Hsp27 expression was recognized mainly in the cytoplasm and nuclei (except the nucleolus) of mouse oocytes. To assess the levels of Hsp27 mRNA in the maturing oocyte, real time RT-PCR analysis was performed using cDNAs equivalent in oocytes at different developmental stages (Figure. 2B). Hsp27 expression dramatically increased following oocyte maturation, Western blot analysis confirmed that Hsp27 at protein level also increased following oocyte maturation, and dramatically increased in MII (Figure. $2 \mathrm{C}$ ), which was consistent with the results of real time RT-PCR and immunofluorescence.

\section{Microinjection of Hsp27 antibody into mouse oocytes}

Polyclonal antibody of Hsp27 was microinjected into oocytes cytoplasm at GV stage to downregulate the activity of Hsp27. After $3 \mathrm{~h}$ of microinjection, the GVBD rate (77.0\%) significantly increased, when compared with normal control $(67.3 \%)$ or IgG-injected control $(64.4 \%)(P<$ $0.01, v s$ IgG-injected group). After $14 \mathrm{~h}$ of microinjection, the maturation rate of MII stage (67.3\%) was also higher than those of two controls (below 60\%) $(P<0.01$, vs IgGinjected group; Table 2). These findings suggested that the lowed Hsp27 activity in mouse oocytes could improve the maturation of oocytes.

Table 3: Stages of oocyte nuclear maturation from the different treatment groups after $3 \mathrm{~h}$ and $14 \mathrm{~h}$ of IVM.

\begin{tabular}{lccc}
\hline Treatment & Total & $\begin{array}{c}\text { No. of oocytes (\%) } \\
\text { Germinal vesicle breakdown }\end{array}$ & Metaphase II \\
\hline control & 319 & $243(76.2)$ & $194(60.8)$ \\
shHsp27(1) & 336 & $298(88.7)^{* *}$ & $257(76.4)^{* *}$ \\
shHsp27(2) & 314 & $270(86.0)^{* *}$ & $232(73.8)^{* *}$ \\
\hline
\end{tabular}

** Values are statistical significance at $P<0.01$ (vs. control). 

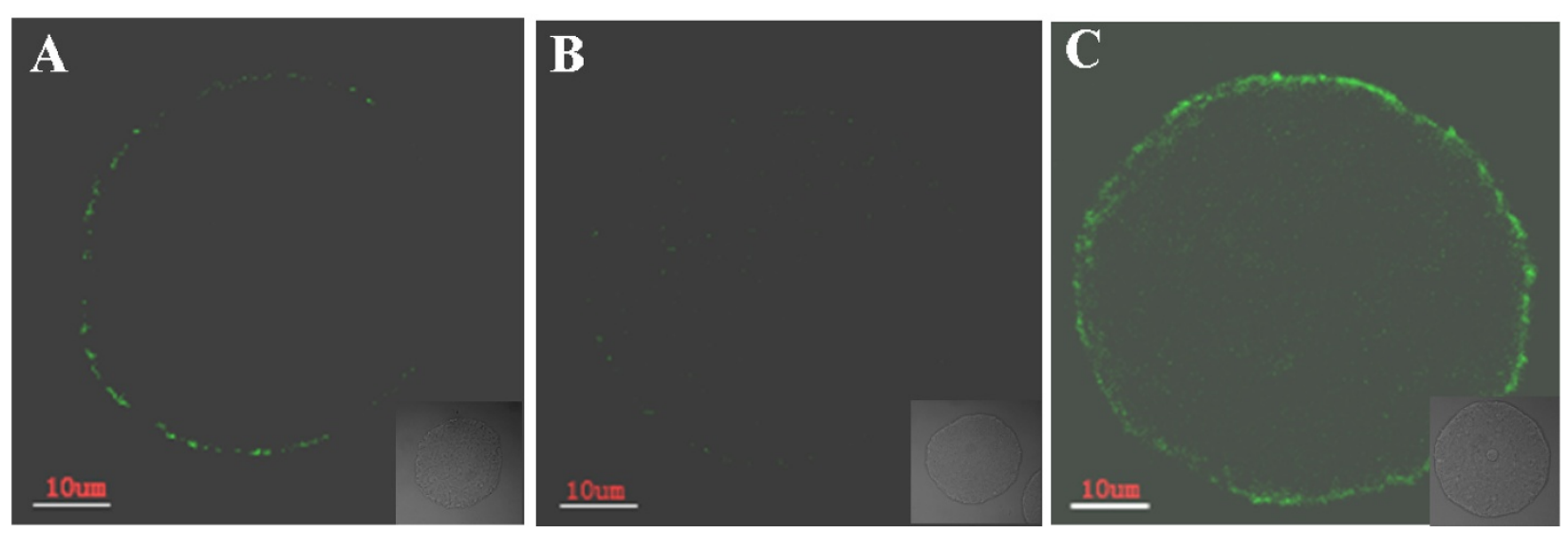

Figure 3 Oocyte classification by Annexin-V staining. (A) necrotic oocytes. Discontinuous green signal was originated from the remnant portions of the membrane. (B) Oocyte Annexin-V negative: no signal in the cytoplasmic membrane. (C) Annexin-V positive (early stage of apoptosis): a clear green signal is observed in the oocyte membrane. Bars $=10 \mu \mathrm{m}$.

\section{Infection of Ad-shHsp27 adenovirus into pellucida-free GV oocytes}

Oocyte maturation of mouse zona-free GV oocytes was significantly improved by infecting with Ad-shHsp27, when compared with negative control at GVBD stage and MII stage (Table 3). The maturation rates of GVBD stage in shHsp27 (1), shHsp27 (2) groups were $86.0 \%$ and 88.7\%, which were higher than control $(76.2 \%)(P<0.01)$. Accordingly, compared with control (60.8\%), the ratios of MII stage in shHsp27 (1) and shHsp27 (2) groups (76.4\% and 73.8\%) were also increased dramatically $(P<0.01)$. Same outcome was found in the antibody microinjection (Table 2).

\section{Annexin-V staining of oocytes}

Oocytes were classified into three groups as Anguita et al described [48]. The first group contained necrotic oocytes with PI-positive red nuclei, indicative of membrane damage. Oocytes with a discontinuous green signal originating from the remnant portions of the membrane were viable non-apoptotic oocytes (Figure. 3A). The second group contained viable oocytes which were negative for Annexin-V staining (Figure. 3B). The third group con- sisted of early apoptotic oocytes with homogeneous Annexin-V-positive signal in the membrane (Figure. 3C).

The ratios of Annexin-V-positive cells in two shHsp27 groups were higher than negative control (Table 4). After $3 \mathrm{~h}$ of treatment, the early apoptotic rate of oocytes infected with Ad-shHsp27 (38.9\%, 36.2\%) was not significantly different from control (33.8\%). The ratios of early apoptotic oocytes in shHsp27-treated groups after $8 \mathrm{~h}$ of treatment were $46.5 \%$ and $45.6 \%$, which were significantly higher than the negative control (34.1\%). The results suggested that Hsp27 downregulation in oocytes could promote the early stage of apoptosis.

\section{Variation of downstream apoptosis-related factors and oocyte secreted factors with defect of Hsp27 protein} To elucidate the involved apoptotic pathway(s), the expressions of four apoptotic factors (caspases 8, caspase 9 , caspase 3 and cytochrome $c$ ) were measured in oocytes following different treatment by real time RT-PCR, immunofluorescence and western blot. As shown in Figure 4 and Figure 5, the results of these assays were accordant. Hsp27 downregulation in mouse oocytes dramatically increased the activitied caspase 8 and cas-

Table 4: The rate of early stage of apoptosis in oocytes at 3 and 8 hours after siRNA adneovirus infection, was evaluated by Annexin-V staining in different groups (Control, shHsp27(1), shHsp27(2)).

\begin{tabular}{|c|c|c|c|c|}
\hline \multirow[b]{2}{*}{ Treatment } & \multicolumn{2}{|r|}{$3 \mathbf{h}$} & \multicolumn{2}{|r|}{$8 \mathrm{~h}$} \\
\hline & Total & No. of early apoptosis oocytes (\%) & Total & No. of early apoptosis oocytes (\%) \\
\hline control & 130 & $44(33.8)$ & 129 & $44(34.1)$ \\
\hline shHsp27(1) & 131 & $51(38.9)$ & 131 & $61(46.5)^{*}$ \\
\hline shHsp27(2) & 149 & $54(36.2)$ & 125 & $57(45.6)^{*}$ \\
\hline
\end{tabular}

$3 \mathrm{~h}$ and $8 \mathrm{~h}$ indicated the time of culture in vitro after adenovirus infection.

*Significant changes within group ( ${ }^{*} P<0.05$ vs. control). 


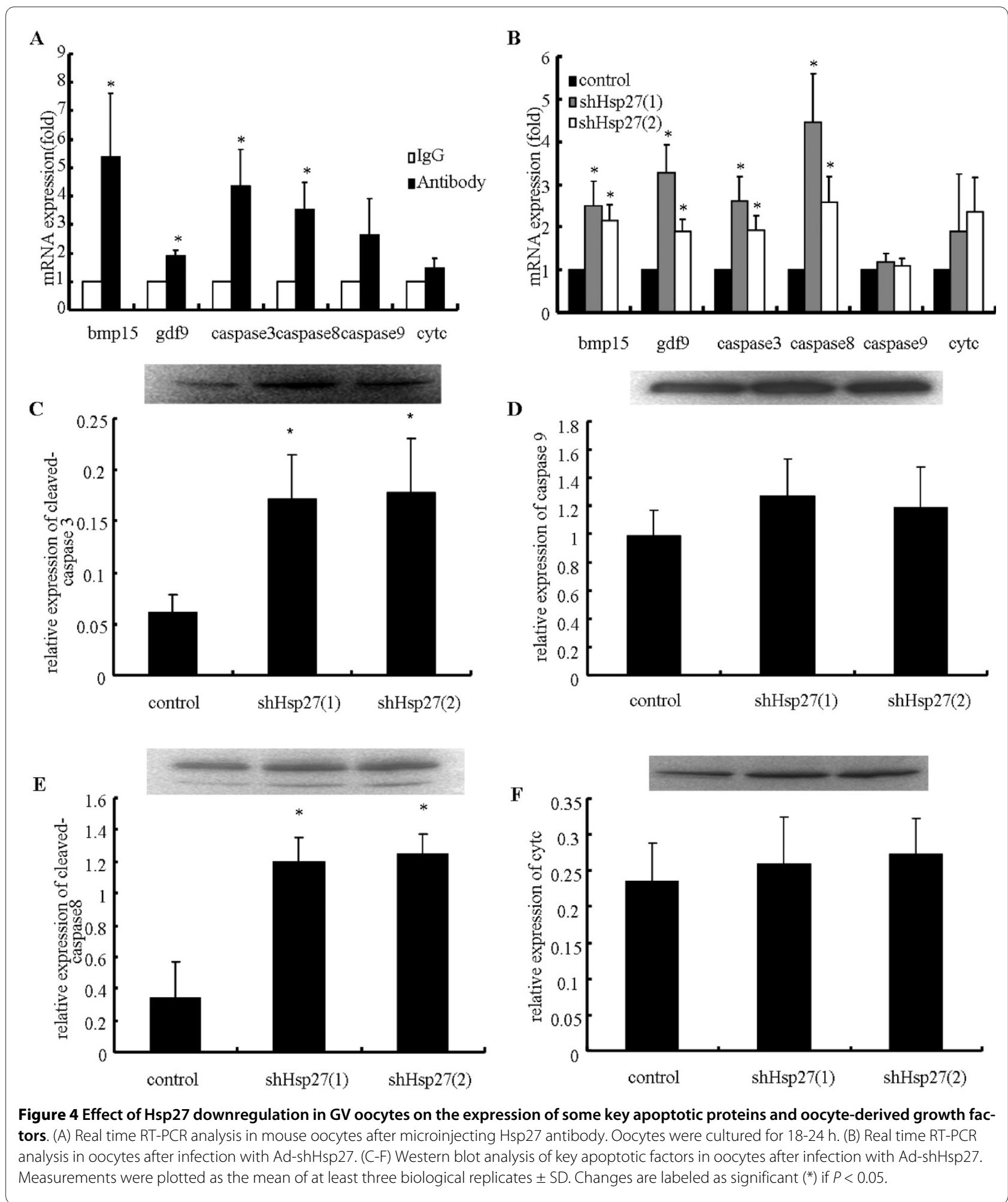

pase 3, while caspase 9 and cytochrome $c$ activities did not change. These results suggested that downregulation of Hsp27 in mouse oocytes resulted in activation exclusively of the extrinsic, caspase 8-mediated apoptotic pathway, rather than the intrinsic, caspase 9-mediated pathway.
In addition, the expressions of two important oocytederived growth factors (bmp 15 and gdf 9) after downregulation of Hsp27 in mouse oocytes were also investigated (Figure. 4A and 4B). The results indicated that bmp 15 and gdf 9 were increased significantly in oocyte after downregulation of Hsp27. 


\section{Discussion}

In the present study, the effect of Hsp27 downregulation on oocyte development and maturation was investigated in the mouse oocyte model cultured in vitro. Expression of Hsp27 gene was downregulated in oocytes using siRNA adenovirus infection, while the activity of Hsp27 was decreased by microinjection of polyclonal Hsp27 antibody into mouse GV oocytes. Interestingly, our results showed that Hsp27 downregulation in mouse oocytes improved oocyte maturation and increased oocyte early stage of apoptosis.

Hsp27 was investigated as an antiapoptotic factor [4951]. Hsp27 could directly bind and co-precipitate with cytochrome $c$, consequently leading to activation of the caspase 9 and caspase 3 in mouse, rat and human cells $[31,33,52,53]$. Kamradt et al reported that Hsp27 could negatively regulate cytochrome $c$ - and caspase 8-dependent activation of caspase 3 in human breast carcinoma cells [54]. To our knowledge, there were few reports about the roles of Hsp27 in oocyte. In this pilot study, after downregulation of Hsp27 in mouse oocytes, the ratio of early stage of apoptosis was significantly increased. Meanwhile, the expression of major apoptotic factors i.e. caspase 3 , caspase 8 was dramatically increased. These results suggested that downregulation of Hsp27 in mouse oocytes might increase early stage of apoptosis by inducing the activation of the extrinsic, caspase 8-mediated apoptotic pathway.

Our results showed that the lowed levels of Hsp27 significantly increased GVBD rate and MII rates in both siRNA infection group and antibody microinjection group when compared with controls, indicating that Hsp27 downregulation was positively related to oocyte maturation. This result was also supported by detecting the expression of two important oocyte-derived growth factors-bmp 15 and gdf 9, which were known to be responsible for controlling fundamental physiological processes in oocyte development and follicular growth [55]. Juengel $e t$ al reported that immunization against gdf 9 and bmp 15 alone or together in cattle oocytes could block folliculogenesis and reduce follicular size, which indicated the critical role of bmp 15 and gdf 9 on oocyte development and follicular growth [56]. In this study, we found that bmp15 and gdf 9 were noticeably upregulated after Hsp27 downregulation in the mouse oocytes model cultured in vitro, suggesting that there was an enhanced effect of downregulated Hsp27 on oocyte development.

Recently, there were numerous studies focused on the relation between early stage of apoptosis and oocyte developmental competency in the pooled oocytes cultured in vitro $[12,48,57,58]$. As we known, early stage of apoptosis was regarded as a sequential, but reversible, process of cell death [10,57]. As Anguita et al and Jaroudi et al indicated, the oocytes undergoing early stage of apoptosis did not mean that they must develop into late apoptosis, early stage of apoptosis oppositely decreased their developmental competence [48,59]. Bilodeau-Goeseels and Panich proved that oocytes with early signs of atresia had good developmental potential by detecting the transcriptional activity in early bovine embryos from different classes of cumulus-oocyte complexes [60]. Additionally, some clinical studies provided consistent results that oocytes from slightly atretic COCs with signs of cumulus expansion had a better embryonic developmental capacity after IVF than those considered to be of the highest quality [61-65]. Concordantly, the percentage of apoptotic cumulus cells increased when COCs were exposed to FSH. Oocytes from those COCs exhibited a higher developmental potential in terms of blastocyst formation rate [66-68]. Those reports suggested that early stage of apoptosis had a positive relation with the improved oocyte developmental potential. In our present study, downregulation of Hsp27 led to a lower antiapoptotic effect and a significant increase in the GVBD rate and MII rate, which was consistent with previous reports [57]. Taking these results together, we speculated that downregulation of Hsp27 induced early oocyte apoptosis, consequently improving oocyte development. In fact, it is difficult at present to understand the molecular mechanism of the correlation between early stage of apoptosis and subsequent maturation of oocyte in follicles in PCOS. Our hypothesis is that downregulation of Hsp27 could be one of the bridges between those events, which is our objectives in future studies.

Previous proteomic analysis comparing normal and PCOS ovarian protein profiles identified that expression of Hsp27 in PCOS ovaries was decreased when compared with normal ovarian tissues [35]. PCOS is known as the most common cause of anovulatory infertility, resulting from a disorder of follicular maturation of uncertain aetiology [15]. Several reports showed that apoptosis was perturbed in PCOS ovaries, with overexpression of apoptotic factors and downregulation of anti-apoptosis factors. However, the others showed the reversed results [69-71]. Das et al reported that there were significant differences in cell death rate and proliferation rate of granulosa cell populations in PCOS patients [72,73]. Oocyte development is interdependent with its surrounding granulose cells[11], and disfunction of granulose cells may contribute to the abnormal folliculogenesis observed in PCOS $[5,74,75]$. Interestingly, we found in this study that the downregulated Hsp27 improved oocyte maturation, which seems to be contradicted with the atresia follicles observed in PCOS. One possible explanation for this contradiction could be that our research was performed in mouse oocyte model cultured in vitro. This model simulates the normal oocyte's development, which could be different from the pathological procedure of 


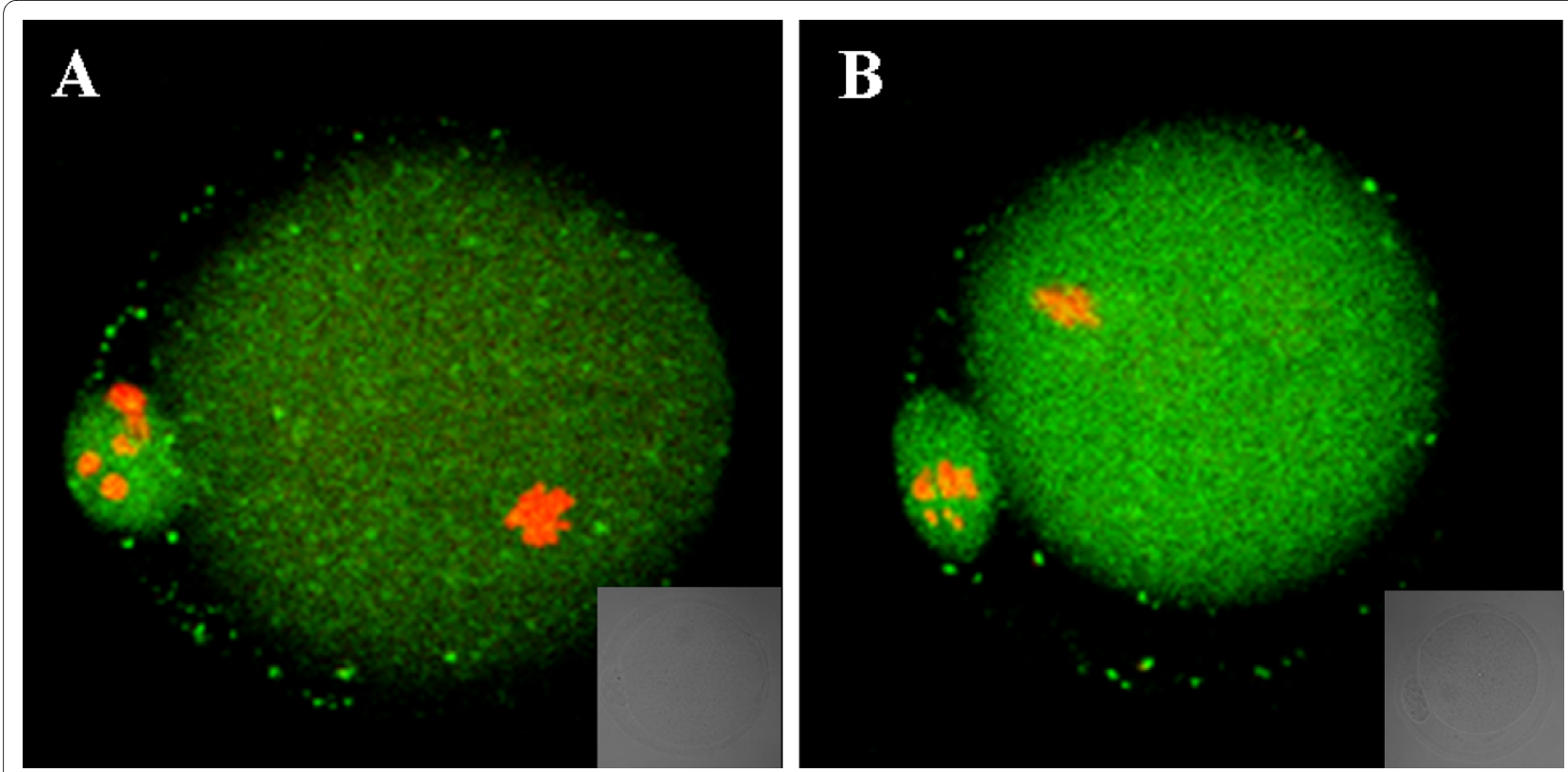

Figure 5 Immunofluorescence staining of cleaved-caspase 3 in oocytes after microinjecting of Hsp27 antibody (The other factors not shown). Oocytes were fixed in 4\% paraformaldehyde after microinjecting of Hsp27 antibody for 36-48 h. Then these oocytes were stained with cleaved-caspase 3 antibody (green). Chromosome material was counterstained with propidium iodide (red). A) IgG-injected oocyte. B) Hsp27 antibody-injected oocyte.

PCOS characterized by an abundance of large but immature follicles. We need more studies on the effects of Hsp27 in PCOS pathophysiology in future studies.

\section{Conclusions}

In conclusion, evidence provided in the present study indicated that downregulation of Hsp27 improved oocyte maturation, and increased early apoptosis of mouse oocytes by triggering the extrinsic, capsase 8-mediated pathway. This is the first report, to our knowledge, to establish a direct link between Hsp27 and oocyte maturation. Relative deficiency of Hsp27 expression in GV oocytes may contribute to the disordered oocyte development in PCOS. Further studies will be required to elucidate the role of Hsp27 in oocyte maturation in vivo and PCOS pathophysiology.

\section{Competing interests}

The authors declare that they have no competing interests.

\section{Authors' contributions}

$J \mathrm{~L}$ carried out the main experiments and wrote the first draft of the manuscript. LBC performed the antibody microinjection. XM, YGC and JYL designed the study and proofread the final manuscript. All authors read and approved the final manuscript.

\section{Acknowledgements}

This study was supported by grants from the China National Natural Science Foundation (Nos.30800394), 973 program (2006CB944005) and Jiangsu Health program [XK02200901(NG09)].

\section{Author Details}

1 Department of life science and technology, China Pharmaceutical University, Nanjing 210038, China and 2 Center of Clinical Reproductive Medicine, First Affiliated Hospital, Nanjing Medical University, Nanjing, 210029, China

Received: 4 February 2010 Accepted: 14 May 2010

Published: 14 May 2010

\section{References}

1. Knochenhauer ES, Key TJ, Kahsar-Miller M, Waggoner W, Boots LR, Azziz R: Prevalence of the polycystic ovary syndrome in unselected black and white women of the southeastern United States: a prospective study. $J$ Clin Endocrinol Metab 1998, 83(9):3078-3082.

2. Sengoku K, Tamate K, Takuma N, Yoshida T, Goishi K, Ishikawa M: The chromosomal normality of unfertilized oocytes from patients with polycystic ovarian syndrome. Hum Reprod 1997, 12(3):474-477.

3. Diamanti-Kandarakis E, Kouli CR, Bergiele AT, Filandra FA, Tsianateli TC, Spina GG, Zapanti ED, Bartzis MI: A survey of the polycystic ovary syndrome in the Greek island of Lesbos: hormonal and metabolic profile. J Clin Endocrinol Metab 1999, 84(11):4006-4011.

4. Asuncion M, Calvo RM, San Millan JL, Sancho J, Avila S, Escobar-Morreale HF: A prospective study of the prevalence of the polycystic ovary syndrome in unselected Caucasian women from Spain. J Clin Endocrinol Metab 2000, 85(7):2434-2438.

5. Willis DS, Watson H, Mason HD, Galea R, Brincat M, Franks S: Premature response to luteinizing hormone of granulosa cells from anovulatory women with polycystic ovary syndrome: relevance to mechanism of anovulation. J Clin Endocrinol Metab 1998, 83(11):3984-3991.

6. Franks $\mathrm{S}$, Mason $\mathrm{H}$, Willis D: Follicular dynamics in the polycystic ovary syndrome. Mol Cell Endocrinol 2000, 163(1-2):49-52.

7. Webber LJ, Stubbs S, Stark J, Trew GH, Margara R, Hardy K, Franks S Formation and early development of follicles in the polycystic ovary. Lancet 2003, 362(9389):1017-1021.

8. Ehrmann DA, Barnes RB, Rosenfield RL: Polycystic ovary syndrome as a form of functional ovarian hyperandrogenism due to dysregulation of androgen secretion. Endocr Rev 1995, 16(3):322-353. 
9. Jonard S, Robert Y, Cortet-Rudelli C, Pigny P, Decanter C, Dewailly D: Ultrasound examination of polycystic ovaries: is it worth counting the follicles? Hum Reprod 2003, 18(3):598-603

10. Morita Y, Tilly JL: Oocyte apoptosis: like sand through an hourglass. Dev Biol 1999, 213(1):1-17.

11. Buccione R, Schroeder AC, Eppig JJ: Interactions between somatic cells and germ cells throughout mammalian oogenesis. Biol Reprod 1990, 43(4):543-547.

12. Feng WG, Sui HS, Han ZB, Chang ZL, Zhou P, Liu DJ, Bao S, Tan JH: Effects of follicular atresia and size on the developmental competence of bovine oocytes: a study using the well-in-drop culture system. Theriogenology 2007, 67(8):1339-1350.

13. Child TJ, Abdul-Jalil AK, Gulekli B, Tan SL: In vitro maturation and fertilization of oocytes from unstimulated normal ovaries, polycystic ovaries, and women with polycystic ovary syndrome. Fertil Steril 2001, 76(5):936-942.

14. Plachot M, Belaisch-Allart J, Mayenga JM, Chouraqui A, Tesquier A, Serkine AM, Boujenah A, Abirached F: [Oocyte and embryo quality in polycystic ovary syndrome]. Gynecol Obstet Fertil 2003, 31(4):350-354

15. Patel SS, Carr BR: Oocyte quality in adult polycystic ovary syndrome. Semin Reprod Med 2008, 26(2):196-203.

16. Dumesic DA, Abbott DH: Implications of polycystic ovary syndrome on oocyte development. Semin Reprod Med 2008, 26(1):53-61.

17. Dumesic DA, Padmanabhan V, Abbott DH: Polycystic ovary syndrome and oocyte developmental competence. Obstet Gynecol Surv 2008, 63(1):39-48.

18. Ptak A, Ludewig G, Kapiszewska M, Magnowska Z, Lehmler HJ, Robertson LW, Gregoraszczuk EL: Induction of cytochromes P450, caspase-3 and DNA damage by PCB3 and its hydroxylated metabolites in porcine ovary. Toxicol Lett 2006, 166(3):200-211.

19. Komiyama J, Nishimura R, Lee HY, Sakumoto R, Tetsuka M, Acosta TJ, Skarzynski DJ, Okuda K: Cortisol is a suppressor of apoptosis in bovine corpus luteum. Biol Reprod 2008, 78(5):888-895.

20. Jensen F, Willis MA, Leopardo NP, Espinosa MB, Vitullo AD: The ovary of the gestating South American plains vizcacha (Lagostomus maximus): suppressed apoptosis and corpora lutea persistence. Biol Reprod 2008, 79(2):240-246.

21. Hussein M: Apoptosis in the ovary: molecular mechanisms. Human reproduction update 2005, 11(2):162.

22. Vaskivuo TE, Tapanainen JS: Apoptosis in the human ovary. Reprod Biomed Online 2003, 6(1):24-35.

23. Diao FY, Xu M, Hu Y, Li J, Xu Z, Lin M, Wang L, Zhou Y, Zhou Z, Liu J, Sha J: The molecular characteristics of polycystic ovary syndrome (PCOS) ovary defined by human ovary cDNA microarray. J Mol Endocrinol 2004, 33(1):59-72.

24. Jansen E, Laven JS, Dommerholt HB, Polman J, van Rijt C, Hurk C van den, Westland J, Mosselman S, Fauser BC: Abnormal gene expression profiles in human ovaries from polycystic ovary syndrome patients. Mol Endocrinol 2004, 18(12):3050-3063.

25. Oksjoki S, Soderstrom M, Inki P, Vuorio E, Anttila L: Molecular profiling of polycystic ovaries for markers of cell invasion and matrix turnover. Fertil Steril 2005, 83(4):937-944.

26. Wood JR, Nelson VL, Ho C, Jansen E, Wang CY, Urbanek M, McAllister JM, Mosselman S, Strauss JF: The molecular phenotype of polycystic ovary syndrome (PCOS) theca cells and new candidate PCOS genes defined by microarray analysis. J Bio/ Chem 2003, 278(29):26380-26390.

27. Landry J, Chretien P, Lambert H, Hickey E, Weber LA: Heat shock resistance conferred by expression of the human HSP27 gene in rodent cells. J Cell Bio/ 1989, 109(1):7-15

28. Oesterreich S, Weng CN, Qiu M, Hilsenbeck SG, Osborne CK, Fuqua SA The small heat shock protein hsp27 is correlated with growth and drug resistance in human breast cancer cell lines. Cancer Res 1993, 53(19):4443-4448.

29. Wheeler DS, Wong HR: Heat shock response and acute lung injury. Free Radic Biol Med 2007, 42(1):1-14

30. Gaitanaki C, Konstantina S, Chrysa S, Beis I: Oxidative stress stimulates multiple MAPK signalling pathways and phosphorylation of the small HSP27 in the perfused amphibian heart. J Exp Biol 2003, 206(Pt 16):2759-2769.

31. Garrido C, Bruey JM, Fromentin A, Hammann A, Arrigo AP, Solary E: HSP27 inhibits cytochrome c-dependent activation of procaspase-9. FASEB J 1999, 13(14):2061-2070.
32. Voss OH, Batra S, Kolattukudy SJ, Gonzalez-Mejia ME, Smith JB, Doseff Al: Binding of caspase- 3 prodomain to heat shock protein 27 regulates monocyte apoptosis by inhibiting caspase-3 proteolytic activation. $J$ Biol Chem 2007, 282(34):25088-25099.

33. Pandey P, Farber R, Nakazawa A, Kumar S, Bharti A, Nalin C, Weichselbaum R, Kufe D, Kharbanda S: Hsp27 functions as a negative regulator of cytochrome c-dependent activation of procaspase-3. Oncogene 2000, 19(16):1975-1981

34. Lanneau D, Brunet M, Frisan E, Solary E, Fontenay M, Garrido C: Heat shock proteins: essential proteins for apoptosis regulation. $J \mathrm{Cell} \mathrm{Mol} \mathrm{Med}$ 2008, 12(3):743-761

35. Ma X, Fan L, Meng Y, Hou Z, Mao YD, Wang W, Ding W, Liu JY: Proteomic analysis of human ovaries from normal and polycystic ovarian syndrome. Mol Hum Reprod 2007, 13(8):527-535.

36. Mahadevan MM, Trounson AO: Removal of the cumulus oophorus from the human oocyte for in vitro fertilization. Fertil Steril 1985, 43(2):263-267

37. Liu DY, Baker HW: Inducing the human acrosome reaction with a calcium ionophore A23187 decreases sperm-zona pellucida binding with oocytes that failed to fertilize in vitro. J Reprod Fertil 1990, 89(1):127-134

38. Ding J, Rana N, Dmowski WP: Intracytoplasmic sperm injection into zona-free human oocytes results in normal fertilization and blastocyst development. Hum Reprod 1999, 14(2):476-478.

39. Ambion - Applied biosystems [http://www.ambion.com]

40. Yang S, Chen W, Stashenko P, Li YP: Specificity of RGS10A as a key component in the RANKL signaling mechanism for osteoclast differentiation. J Cell Sci 2007, 120(Pt 19):3362-3371.

41. Judge AD, Sood V, Shaw JR, Fang D, McClintock K, MacLachlan I: Sequence-dependent stimulation of the mammalian innate immune response by synthetic siRNA. Nat Biotechnol 2005, 23(4):457-462

42. Shen C, Buck AK, Liu X, Winkler M, Reske SN: Gene silencing by adenovirus-delivered siRNA. FEBS Lett 2003, 539(1-3):111-114.

43. He TC, Zhou S, da Costa LT, Yu J, Kinzler KW, Vogelstein B: A simplified system for generating recombinant adenoviruses. Proc Natl Acad SC USA 1998, 95(5):2509-2514.

44. Dai $Y$, Lee $C$, Hutchings A, Sun Y, Moor R: Selective requirement for $\mathrm{Cdc} 25 \mathrm{C}$ protein synthesis during meiotic progression in porcine oocytes. Biol Reprod 2000, 62(3):519-532.

45. Livak KJ, Schmittgen TD: Analysis of relative gene expression data using real-time quantitative PCR and the 2(-Delta Delta C(T)) Method. Methods 2001, 25(4):402-408.

46. Von Stetina JR, Tranguch S, Dey SK, Lee LA, Cha B, Drummond-Barbosa D: alpha-Endosulfine is a conserved protein required for oocyte meiotic maturation in Drosophila. Development 2008, 135(22):3697-3706.

47. Zhou Y, Ma C, Karmouch J, Katbi HA, Liu XJ: Antiapoptotic role for ornithine decarboxylase during oocyte maturation. Mol Cell Biol 2009 29(7):1786-1795.

48. Anguita B, Vandaele L, Mateusen B, Maes D, Van Soom A: Developmental competence of bovine oocytes is not related to apoptosis incidence in oocytes, cumulus cells and blastocysts. Theriogenology 2007, 67(3):537-549.

49. Ciocca DR, Oesterreich S, Chamness GC, McGuire WL, Fuqua SA: Biological and clinical implications of heat shock protein 27,000 (Hsp27): a review. J Nat/ Cancer Inst 1993, 85(19):1558-1570.

50. Concannon CG, Gorman AM, Samali A: On the role of Hsp27 in regulating apoptosis. Apoptosis 2003, 8(1):61-70.

51. Son GH, Geum D, Chung S, Park E, Lee KH, Choi S, Kim K: A protective role of 27-kDa heat shock protein in glucocorticoid-evoked apoptotic cell death of hippocampal progenitor cells. Biochem Biophys Res Commun 2005, 338(4):1751-1758

52. Paul C, Manero F, Gonin S, Kretz-Remy C, Virot S, Arrigo AP: Hsp27 as a negative regulator of cytochrome $\mathrm{C}$ release. $\mathrm{Mol} \mathrm{Cell} \mathrm{Biol} 2002$ 22(3):816-834

53. Whitlock NA, Lindsey K, Agarwal N, Crosson CE, Ma JX: Heat shock protein 27 delays $\mathrm{Ca} 2+$-induced cell death in a caspase-dependent and independent manner in rat retinal ganglion cells. Invest Ophthalmol Vis Sci 2005, 46(3): 1085-1091.

54. Kamradt MC, Chen F, Cryns VL: The small heat shock protein alpha Bcrystallin negatively regulates cytochrome c- and caspase-8dependent activation of caspase- 3 by inhibiting its autoproteolytic maturation. J Biol Chem 2001, 276(19):16059-16063. 
55. Su YQ, Sugiura K, Wigglesworth K, O'Brien MJ, Affourtit JP, Pangas SA, Matzuk MM, Eppig JJ: Oocyte regulation of metabolic cooperativity between mouse cumulus cells and oocytes: BMP15 and GDF9 control cholesterol biosynthesis in cumulus cells. Development 2008, 135(1):111-121.

56. Juengel JL, Hudson NL, Berg M, Hamel K, Smith P, Lawrence SB, Whiting L, McNatty KP: Effects of active immunization against growth differentiation factor 9 and/or bone morphogenetic protein 15 on ovarian function in cattle. Reproduction 2009, 138(1):107-114.

57. Li HJ, Liu DJ, Cang M, Wang LM, Jin MZ, Ma YZ, Shorgan B: Early apoptosis is associated with improved developmental potential in bovine oocytes. Anim Reprod Sci 2009, 114(1-3):89-98.

58. Zeuner A, Muller K, Reguszynski K, Jewgenow K: Apoptosis within bovine follicular cells and its effect on oocyte development during in vitro maturation. Theriogenology 2003, 59(5-6):1421-1433.

59. Jaroudi S, SenGupta S: DNA repair in mammalian embryos. Mutat Res 2007, 635(1):53-77.

60. Bilodeau-Goeseels S, Panich P: Effects of oocyte quality on development and transcriptional activity in early bovine embryos. Anim Reprod Sci 2002, 71(3-4):143-155.

61. Blondin P, Sirard MA: Oocyte and follicular morphology as determining characteristics for developmental competence in bovine oocytes. Mol Reprod Dev 1995, 41(1):54-62.

62. Hagemann LJ, Beaumont SE, Berg M, Donnison MJ, Ledgard A, Peterson AJ, Schurmann A, Tervit HR: Development during single IVP of bovine oocytes from dissected follicles: interactive effects of estrous cycle stage, follicle size and atresia. Mol Reprod Dev 1999, 53(4):451-458.

63. Moor RM, Lee C, Dai YF, Fulka J Jr: Antral follicles confer developmental competence on oocytes. Zygote 1996, 4(4):289-293.

64. de Wit AA, Wurth YA, Kruip TA: Effect of ovarian phase and follicle quality on morphology and developmental capacity of the bovine cumulusoocyte complex. J Anim Sci 2000, 78(5):1277-1283.

65. Boni R, Cuomo A, Tosti E: Developmental potential in bovine oocytes is related to cumulus-oocyte complex grade, calcium current activity, and calcium stores. Biol Reprod 2002, 66(3):836-842.

66. Izadyar F, Zeinstra E, Bevers MM: Follicle-stimulating hormone and growth hormone act differently on nuclear maturation while both enhance developmental competence of in vitro matured bovine oocytes. Mol Reprod Dev 1998, 51(3):339-345.

67. van Tol HT, van Eijk MJ, Mummery CL, Hurk R van den, Bevers MM: Influence of FSH and hCG on the resumption of meiosis of bovine oocytes surrounded by cumulus cells connected to membrana granulosa. Mol Reprod Dev 1996, 45(2):218-224.

68. Rubio Pomar FJ, Roelen BA, Slot KA, van Tol HT, Colenbrander B, Teerds KJ: Role of Fas-mediated apoptosis and follicle-stimulating hormone on the developmental capacity of bovine cumulus oocyte complexes in vitro. Biol Reprod 2004, 71(3):790-796.

69. Laven JS, Imani B, Eijkemans MJ, de Jong FH, Fauser BC: Absent biologically relevant associations between serum inhibin $B$ concentrations and characteristics of polycystic ovary syndrome in normogonadotrophic anovulatory infertility. Hum Reprod 2001, 16(7):1359-1364.

70. Hughes C, Elgasim M, Layfield R, Atiomo W: Genomic and post-genomic approaches to polycystic ovary syndrome--progress so far: Mini Review. Hum Reprod 2006, 21(11):2766-2775.

71. Cataldo NA, Dumesic DA, Goldsmith PC, Jaffe RB: Immunolocalization of Fas and Fas ligand in the ovaries of women with polycystic ovary syndrome: relationship to apoptosis. Hum Reprod 2000, 15(9):1889-1897.

72. Das M, Djahanbakhch O, Hacihanefioglu B, Saridogan E, Ikram M, Ghali L, Raveendran M, Storey A: Granulosa cell survival and proliferation are altered in polycystic ovary syndrome. J Clin Endocrinol Metab 2008, 93(3):881-887.

73. Vendola KA, Zhou J, Adesanya OO, Weil SJ, Bondy CA: Androgens stimulate early stages of follicular growth in the primate ovary. J Clin Invest 1998, 101(12):2622-2629.

74. Erickson GF, Magoffin DA, Garzo VG, Cheung AP, Chang RJ: Granulosa cells of polycystic ovaries: are they normal or abnormal? Hum Reprod 1992, 7(3):293-299.

75. Jakimiuk AJ, Weitsman SR, Navab A, Magoffin DA: Luteinizing hormone receptor, steroidogenesis acute regulatory protein, and steroidogenic enzyme messenger ribonucleic acids are overexpressed in thecal and granulosa cells from polycystic ovaries. J Clin Endocrinol Metab 2001, 86(3):1318-1323.

doi: $10.1186 / 1477-7827-8-47$

Cite this article as: Liu et al., Downregulation of both gene expression and activity of Hsp27 improved maturation of mouse oocyte in vitro Reproductive Biology and Endocrinology 2010, 8:47

\section{Submit your next manuscript to BioMed Central and take full advantage of:}

- Convenient online submission

- Thorough peer review

- No space constraints or color figure charges

- Immediate publication on acceptance

- Inclusion in PubMed, CAS, Scopus and Google Scholar

- Research which is freely available for redistribution

Submit your manuscript at www.biomedcentral.com/submit
C) Biomed Central 